\title{
The Effects of Unstable Macroeconomic Indicators on Stock Price Behavior of Banking Sector in the Nigerian Stock Market
}

\author{
Ibrahim Bello Abdullahi* \\ Department of Finance, Faculty of Management, University of Ilorin \\ Ilorin, PMB 1515, Nigeria \\ abibrahim@unilorin.edu.ng
}

Received: $16^{\text {th }}$ October 2019/ Revised: $29^{\text {th }}$ January $2020 /$ Accepted: $12^{\text {th }}$ March 2020

How to Cite: Abdullahi, I. B. (2020). The Effects of Unstable Macroeconomic Indicators on Stock Price Behavior of Banking Sector in the Nigerian Stock Market. Binus Business Review, 11(2), 71-78. https://doi.org/10.21512/bbr.v11i2.6047

\begin{abstract}
The research aimed to investigate the stock price behavior of banking sector in response to unstable macroeconomic variables in the Nigerian stock market. The research employed ex-post facto research design, and the data were subjected to Autoregressive Distributed Lag method of analysis to examine both the short and long run of the studied variables between 2009 and 2018. The findings reveal significant negative effects of interest rate and foreign reserves on the stock price behavior of the banking sector in the long run. Meanwhile, the inflation rate has a significant positive influence on stock price behavior. Then, the exchange rate is not statistically significant in influencing stock price behavior in the Nigerian stock market. It can be concluded that the stock price behavior of banking sector is influenced by foreign external reserve, interest rate, and inflation rate. It is recommended that the monetary policy rate should be reduced to decrease the cost of borrowing and enhance liquidity level in the stock market.
\end{abstract}

Keywords: macroeconomic indicators, stock price behavior, banking sector, Nigerian stock market

\section{INTRODUCTION}

Living in an ever-changing world of globalization and technological advancement with uncertainties around the globe, investors and financial analysts have realized the importance of understanding stock price in response to unstable macroeconomic variables. It is due to increasing fluctuations in some of the macroeconomic variables that often affect investment and return. Hence, investors are faced with an uncontrollable risk of loss of assets (Uwubanmwen \& Eghosa, 2015).

Celebi and Hönig (2019) stated that uncertainties in macroeconomic variables largely affected stock prices and the entire market. An efficient and stable capital market depended mostly on the macroeconomic environment within its spheres of operation. Similarly, Omankhanlen, Senibi, and Senibi (2016), Gilbert, Scotti, Strasser, and Vega (2017), Pal and Garg (2019),
Asamoah, Baiden, and Nani (2019), and Mbulawa (2015) agreed that the capital market often reacted to the macroeconomic environment such as political and economic climates (exchange rate, interest rate, gross domestic product, and others). It was due to the interactions between the surplus unit and the productive sector of the economy. It is no doubt that a stable macroeconomic environment is a catalyst for the growth of the capital market and the development of the economy.

Macroeconomic indicators in Nigeria have affected different sectors in the Nigerian stock market because of its heterogeneity. The banking sector is the spine of the Nigerian stock market as it constitutes the most significant percentage of the total market capitalization and the highest traded stock (Ajayi, 2013). Over the years, the stock performance of banking sector has been a catalyst and a pointer to the growth and development of the capital market in 
Nigeria (Omankhanlen et al., 2016). However, the banking sector stock has been affected since the global financial crisis due to the international credit crunch. Thus, it causes panic in the banking sector.

Moreover, the banking sector also experiences a continuous decline in stock price. It is due to instability in key macroeconomic variables such as foreign exchange rate, inflation rate, and foreign external reserves (Omankhanlen et al., 2016). Notably, previous researchers like Ouma and Muriu (2014), Mbulawa (2015), Omankhanlen et al. (2016), Ray and Saha (2016), and Khalid and Khan (2017) examined macroeconomic variables and stock market returns on an aggregate basis. Despite that, the research on macroeconomic variables and stock price behavior of banking sector is still scarce in the literature.

Empirically, Ouma and Muriu (2014) examined stock market returns and macroeconomic variables in Kenya. They employed Ordinary Least Square (OLS) to examine the influence of interest rates, exchange rate, inflation rate, and Gross Domestic Product (GDP) on the stock market return. The results showed significant negative effects of the exchange rate on stock market return. Meanwhile, the inflation rate and GDP were significant. Those impacted the stock return positively. They concluded that interest rate was not a determining factor of the stock market return in Kenya.

Then, Mbulawa (2015) analyzed the interdependence between interest rates, exchange rates, and stock market performance. The research used the Vector Error Correction Model on monthly data in two inflationary periods (the pre-hyperinflationary and hyperinflationary period). The research revealed that the interest rate had a mixed impact on the performance of the stock market in the pre-hyper inflationary phase. Also, bidirectional causality was found between the stock market and exchange rates. However, a positive impact of the exchange rate was found on stock market performance amidst the hyperinflationary period.

Ray and Saha (2016) analyzed stock returns and macroeconomic variables of the Bombay Stock Exchange (BSE) using inflation rate, GDP, exchange rate, gold price, and oil price. They used the Johansen co-integration test to investigate the long-run relationship between the variables. They also examined stock returns volatility in response to changes in macroeconomic variables using GARCH $(1,1)$ model. They found a significant negative impact of the exchange rate on stock returns, while other variables were negative and insignificant to BSE stock return.

Similarly, Omankhanlen et al. (2016) examined macroeconomic indicators and stock price movement in Nigeria between 1985 and 2014 using co-integration and Vector Error Correction Model. They concluded that the inflation rate and the exchange rate had a significant influence on the stock price movement in Nigeria. Besides, Okech and Mugambi (2016) studied the impact of macroeconomic variables such as exchange rate, interest rate, inflation rate, and
GDP on stock returns of listed banks in the Nairobi Securities Exchange. They employed OLS regression between 2000 and 2015 using quarterly data. The results showed that the exchange rate, interest rate, and inflation had a significant impact on the stock returns of the banking sector in Nairobi. However, an insignificant influence was found between GDP and stock returns of the banking sector in Nairobi.

Khalid and Khan (2017) empirically analyzed the link between stock market return, interest rate, inflation rate, and exchange rate in Pakistan. Autoregressive Distributed Lag (ARDL) was used to investigate the long run co-integrating relationship between the variables. They found the existence of a long-run relationship between exchange rate, inflation rate, interest rate, and stock market returns. The results also implied that the exchange rate was insignificant but positive on Pakistan Stock Exchange (PSX) index. Meanwhile, the inflation rate was positively significant to the stock market return. Then, interest rates had a significant negative impact in the long run on the PSX market returns.

Next, Kurotamunobaraomi and Ebiware (2017) examined inflation rates and stock prices of quoted firms in Nigeria using OLS regression, Johansen Co-integration, and Granger Causality test to see the influence of exchange rate, money supply, interest rate, and inflation rate on the stock price. They found no long-run relationship between the variables. They concluded that the exchange rate, money supply, and inflation rate portrayed a statistically significant impact on stock prices in the short run. However, the interest rate showed a negative impact on stock prices. Furthermore, the results found unidirectional causal relationships from stock price to interest rate and exchange rate.

Rjoub, Civicir, and Resatoglu (2017) investigated micro and macroeconomic determinants of the stock price of Turkish banking sector using panel data analysis. Then, Wooldridge (2013) employed Dumitrescu-Hurlin Panel Granger Causality for ten years between 1995 and 2015. The researcher concluded that interest rate, asset quality, management quality, and money supply influenced Turkish banking sector stock prices significantly.

From the review of empirical studies, there is no doubt that the impact of unstable macroeconomic variables on stock price behavior has received considerable attention in literature across the globe. It is important to note that unstable macroeconomic variables affect sectors of the economy differently due to the heterogeneity of the market. Most of these studies in literature focused on the effects of unstable macroeconomic variables on stock price behavior in the market at the aggregate level. Therefore, the researcher focuses on a specific sector (banking sector), which is considered the most capitalized and traded stock sector in the Nigerian stock market.

Also, previous researchers focus more on examining unstable macroeconomic variables and 
stock return using interest rate, inflation rate, and exchange rate as the significant macroeconomic variables and neglecting foreign reserve. Wooldridge (2013) suggested that the impact of one variable on the other variables could not be established unless other relevant variables were held constant. Hence, the researcher identifies foreign reserve as a macroeconomic gap by including it among other macroeconomic variables in examining the effect of unstable macroeconomic variables on stock price behavior in the Nigerian banking sector.

Theoretically, the research is built upon Arbitrage Pricing Theory (APT). The theory was propounded by Ross (1976) and globally accepted as the theory that bound macroeconomic variables and stock price as a result of the drawback of the Capital Asset Pricing Model (CAPM). It is proven by its unrealistic assumptions, the difficulty of empirical testing, and the fact that the expected rate of return of a security is a function of only one factor such as the general stock market. Meanwhile, APT is based on the assumption that equilibrium market prices should be perfect in such a way that the price will move to eliminate buying and selling without arbitrage opportunities (Gilbert et al., 2017).

Investors have homogeneous risk expectations and are risk-averse with no existing transaction cost and tax with the market. Hence, APT concerns a multi-factor model that is multiple beta $(\beta)$ model. The theory argues that risk factors in the APT arise from changes in some fundamental economic and financial variables such as interest rates, inflation, money supply, oil prices, and exchange rate among others that can also influence the price of an asset (Uwubanmwen \& Eghosa, 2015). The theory shows that the expected return of a financial asset can be modeled as a linear function of several macro-economic factors or theoretical market indices. A factor-specific beta coefficient represents the sensitivity to changes in each factor. The model-derived rate of return is used to price the asset correctly as the asset price should equal to the expected end of the period price, which is discounted at the rate implied by the model. If the price diverges, arbitrage will return it to the expected price.

This research aims to examine the effects of unstable macroeconomic indicators on the stock price behavior of banking sector in the Nigerian stock market. It is in response to unstable macroeconomic variables in Nigeria. It focuses on the foreign reserves, foreign exchange rate, interest rate, and inflation rate.

\section{METHODS}

The research adopts an ex-post facto research design by relying on a secondary source such as the data for the studied variables. Monthly secondary data are from the statistical bulletin of Central Bank of Nigeria and fact books of various editions in Nigerian Stock Exchange spanning from 2008 to 2018. The year (2008) represents the global financial meltdown across the globe. It also represents the year in which the Nigerian Stock Exchange came up with a sectoral index to meet the international market standard index for measuring global and local economic and sectoral performance sequel to the global financial crises. The banking sector is the main focus of this research because it constitutes the largest traded stock on the Nigerian stock market. It is also the sector with the highest market capitalization.

The research uses Augmented Dickey Fuller (ADF) nit root test to verify the order of stationarity of the data. Then, a bond test is also conducted to assess whether there is long-run co-integration among the variables.

The research also uses ARDL model proposed by Pesaran, Shin, and Smith (2001) to examine the long- and short-run effects of unstable macroeconomic variables on the stock price behavior of the banking sector in Nigeria stock market. The ARDL model is applicable for both non-stationary time series as well as for times series with mixed order of integration. It is capable of assessing short-run dynamic effects without losing information on the long-run relationship among financial time series data (Shrestha \& Bhatta, 2018). Therefore, the ARDL model in the research is as follows:

$$
\begin{aligned}
& \Delta B N K A S I_{t}=\alpha_{0 t}+\sum_{i=0}^{n} \beta_{i} \Delta B N K A S I_{t-i}+ \\
& \sum_{i=0}^{n} \gamma_{i} \Delta F E R_{t-i}+\sum_{i=0}^{n} \delta_{i} \Delta F R_{t-i}+ \\
& \sum_{i=0}^{n} \theta_{i} \Delta I N T_{t-i}+\sum_{i=0}^{n} \vartheta_{i} \Delta I N F_{t-i}+ \\
& \emptyset_{1} B N K A S I_{t-1}+\emptyset_{2} F E R_{t-1}+\emptyset_{3} F R_{t-1}+ \\
& \emptyset_{4} I N T_{t-1}+\emptyset_{5} I N F_{t-1}+e c t+\varepsilon_{t}
\end{aligned}
$$

Which:

$\begin{array}{ll}\Delta & =\text { the first difference operator } \\ \text { ect } & =\text { error correction term } \\ \text { BNKASI } & =\text { all share index in banking sector } \\ \text { FER } & =\text { foreign exchange rate } \\ \text { FR } & =\text { foreign reserve } \\ \text { INT } & =\text { interest rate } \\ \text { INF } & =\text { inflation rate } \\ \varepsilon_{t} & =\text { disturbance term } \\ t & =\text { observed time }\end{array}$

\section{RESULTS AND DISCUSSIONS}

The descriptive statistics results of the dependent and independent variables are presented in Table 1. Key figures, including mean, Standard Deviation (SD), and minimum and maximum values, are reported to give the overall description of data used in the model. Moreover, the skewness, kurtosis, and Jarque-Bera results are also presented to test for 
the normality of data.

The all share index in the banking sector has a monthly average of 371,35 . Meanwhile, the standard deviation stands at 74,36 , indicating a minimal spread over the period. The maximum all share index for the banking sector in a month is 577,14 , and the minimum all share index is 223,74 . The skewness and kurtosis values are low. It means that the data are not skewed and likely to be normally distributed. Furthermore, Jarque-Bera statistic shows that the data are not normally distributed with a significant value of 1,73 and $p$-value of 0,042 . It implies a rejection of the null hypothesis of normality.

The mean value of the foreign exchange rate is 218,74 . Then, the maximum exchange rate experienced in a month is $\$ 494,70$, and the minimum exchange rate is $\$ 118,69$ with a standard deviation of 99,42 . It illustrates a high variability in the value of the Naira to US dollar within the period studied. It is evidence to show that Naira has not been relatively stable over the years. Moreover, the skewness and kurtosis values reveal that the data are skewed and likely not to be normally distributed. Then, JarqueBera statistic confirms that the data are not normally distributed with value of 28,56 and $p$-value of 0,000 , indicating there is sufficient evidence to reject the null hypothesis of normality.

In addition, the minimum value of the inflation rate is 7,71 . However, the maximum value is 18,72 with an average value of 11,91 . It indicates a wide range of inflation rate in Nigeria. The skewness and kurtosis values show that the data are skewed and have a tail. It is likely not to be normally distributed. Then, Jarque-Bera statistic confirms that the data are not normally distributed with the value of 7,03 and $p$-value of 0,030 , implying there is sufficient evidence to reject the null hypothesis of normality.

The monthly average for the foreign reserve is $38.704,7$ million US dollars. The highest foreign reserves in a month are 62.081,9 million US dollars, and the lowest foreign reserves are 23.689,9 million US dollars. The standard deviation for foreign reserves over the period is $9.125,7$ million US dollars. Meanwhile, the skewness and kurtosis values of 0,68 and 2,94 show that the data are skewed and likely not to be normally distributed. Jarque-Bera statistic also implies that the data are not normally distributed with the value of 10,05 and $p$-value of 0,007 , indicating there is sufficient evidence to reject the null hypothesis of normality.

The results also reveal that the interest rate is $11,01 \%$. The maximum value of the interest rate in a month is $14 \%$, and the minimum value is $6 \%$. It indicates a high disparity in the interest rate in Nigeria over the period. Meanwhile, the standard deviation for interest rate over the period is $2,68 \%$. The skewness and kurtosis values of $-0,74$ and 2,29 mean the data are skewed and likely not to be normally distributed.

Table 1 Summary of Descriptive

Statistics of Variables

\begin{tabular}{lcccccccc}
\hline Statistics & Mean & Max. & Min. & SD & Skew & Kurt & $\begin{array}{c}\text { Jarque-Bera } \\
(\text { JB })\end{array}$ & Prob. \\
\hline BNKASI & 371,35 & 577,14 & 223,74 & 74,36 & 0,29 & 2,89 & 1,73 & 0,042 \\
FER & 218,74 & 494,70 & 118,69 & 99,42 & 1,15 & 2,94 & 28,56 & 0,000 \\
INF & 11,91 & 18,72 & 7,71 & 3,05 & 0,39 & 2,16 & 7,03 & 0,030 \\
FR & $38.704,7$ & $62.081,9$ & $23.689,9$ & $9.125,7$ & 0,68 & 2,94 & 10,05 & 0,007 \\
INT & 11,01 & 14,0 & 6,0 & 2,68 & $-0,74$ & 2,29 & 14,58 & 0,000 \\
\hline
\end{tabular}

(Source: Researcher's Computations, 2019)

Table 2 Pairwise Correlation Matrix

\begin{tabular}{lccccc}
\hline & Banking & Exchange rate & Inflation & Foreign reserves & Interest rate \\
\hline Banking & 1,0 & & & & \\
Exchange rate & $-0,10$ & 1,0 & & & \\
Inflation & $-0,18$ & 0,64 & 1,0 & 1,0 & 1,0 \\
Foreign reserves & 0,62 & $-0,39$ & $-0,29$ & $-0,19$ & \\
Interest rate & $-0,04$ & 0,63 & 0,04 & & \\
\hline
\end{tabular}

(Source: Researcher's Computations, 2019) 
Then, Jarque-Bera statistic shows that the data are not normally distributed with the value of 14,58 and p-value of 0,000 , indicating there is sufficient evidence to reject the null hypothesis of normality.

Table 2 presents the result of pairwise correlation analysis. It is used to examine the relationships that exist among the variables of the model. Most importantly, it is to check that there are no relationships with a correlation coefficient of as high as 0,8 . It is commonly used as a benchmark to signal problematic multicollinearity. The results show that all the correlation coefficients are below 0,8 . It is an indication of no problematic multi-colinearity in the model.

The ADF unit root results presented in Table 3 reveal that at $5 \%$ significant level, the inflation rate is stationary at levels (integrated-of-order-zero series, such as $\mathrm{I}(0)$ series $)$. All other variables, such as all share index in the banking sector, foreign exchange rate, foreign reserves, and interest rate, are not stationary series at level but are integrated-of-order-one series $\mathrm{I}(1)$. It is proven from their respective $\mathrm{p}$-values being higher than 0,05 . Moreover, their respective test statistics are less than their critical values. Meanwhile, at the first difference, their respective $p$-values are less than 0,05 , and their respective test statistics are higher than their critical values. The outcome of the unit root test requires the ARDL bounds test approach to cointegration, developed by Pesaran et al. (2001). It is to verify whether a long-run equilibrating relationship exists among the variables.

The ARDL bounds test states a null hypothesis of no long-run relationships among the variables of a model. If the F-statistic value is higher than I(1) bound, the null hypothesis should be rejected. It will accept the null hypothesis if the value is less than $\mathrm{I}(0)$ bound. On the other hand, the test is inconclusive if the F-statistic value falls in between the bounds. The F-statistic value of the test is 4,69, with four independent variables included in the model. The $\mathrm{I}(0)$ and I(1) bounds at 5\% significance level for the model are 3,12 and 4,25 respectively. It shows that the F-statistic is more significant than I(1) bound of the models, indicating a long-run co-integrating relationship between the variables. The results are in Table 4.

The result presented in Table 5 seeks to examine the impact of macroeconomic variables on the stock price behavior of banking sector. The model is selected out of 12.500 evaluated models through the automatic model selection method of Akaike information criterion. The short-run model indicates that foreign reserves, interest rate, and inflation rate are major short-run determinants of stock price behavior of the banking sector. These are shown from each of their p-value which is lower than the conventional levels of significance. It makes them statistically significant in influencing stock price behavior of banking sector. However, the foreign exchange rate is not short-run determinants of stock price behavior of banking sector.

Moreover, foreign reserves and interest rate show negative signs. It means that they influence the stock price behavior of banking sector negatively. Meanwhile, the inflation rate has a positive sign. It indicates the positive influence in the stock price behavior of banking sector. The significant negative coefficient of foreign reserves illustrates that a percentage increase in foreign reserves will lead to a decline in the stock price behavior of banking sector by $6,08 \%$, and vice versa. Similarly, the significant negative coefficient of interest rate shows that a percentage increase in the interest rate will lead to a decline in the stock price behavior of banking sector by $0,14 \%$, and vice versa.

On the contrary, the significant positive coefficient of the inflation rate shows the increase in the inflation rate will lead to an increase in the stock price behavior of banking sector by $0,33 \%$, and vice versa. The result also includes the lag effect on the stock price behavior of banking sector which is seen to be statistically insignificant. The error correction term (cointeq) in one period lag is negative and statistically significant. It is a condition to achieve convergence of the model, which measures the speed of adjustment to long-run equilibrium. Its significant negative coefficient indicates that about $67,5 \%$ of disequilibrium is adjusted in each period (month), and it will take less than two periods for equilibrium to be achieved.

Moreover, in the long-run estimation, the foreign reserves and interest rate show negative signs, indicating they influence stock price behavior of banking sector negatively. However, the inflation rate shows a positive sign implying it influences the stock price behavior of banking sector positively. The significant negative coefficient of foreign reserves means that an increase in foreign reserves will lead to a long-run decline in stock price behavior of banking sector by $9,0 \%$, and vice versa. Similarly, the significant negative coefficient of interest rate indicates that an increase in the interest rate will lead to a longrun decline in banking sector stock prices by $0,21 \%$, and vice versa. On the contrary, the significant positive coefficient of inflation rate shows that an increase in the inflation rate will lead to a long-run increase in banking sector stock prices by $0,48 \%$, and vice versa. On the other hand, the p-values of the exchange rate are higher than the conventional levels of significance (even 10\%), making it statistically insignificant in influencing banking sector stock prices in the long run.

The R-squared for this model shows the value of 0,848 . It means that the model explains about $84,8 \%$ of variations in the stock price behavior of banking sector. F-statistic has a value of 74,0, and $p$-value of 0,000 states that the overall model is statistically significant. It implies that the model is a good fit. Then, the Durbin-Watson statistic indicates that the model is free from the problem of serial correlation as its reported value can be approximated to 2 .

The findings reveal that foreign reserves have significant negative effects on the stock price behavior of banking sector. It may be due to the sudden and 
Table 3 Augmented Dickey-Fuller Unit Root Test

\begin{tabular}{|c|c|c|c|c|c|c|c|}
\hline \multirow[b]{2}{*}{ Variables } & \multirow[b]{2}{*}{ T-statistic } & \multirow{2}{*}{$\frac{\text { At level }}{\text { Crit.Value }}$} & \multicolumn{5}{|c|}{ At First Difference } \\
\hline & & & P-Value & T-statistic & Crit.Value & P-Value & $\begin{array}{c}\text { Order of } \\
\text { Integration }\end{array}$ \\
\hline Banking & $-4,12$ & $-5,17$ & 0,45 & $-10,04$ & $-5,17$ & 0,00 & $\mathrm{I}(1)$ \\
\hline Exchange rate & $-4,65$ & $-5,17$ & 0,17 & $-10,60$ & $-5,17$ & 0,00 & $\mathrm{I}(1)$ \\
\hline Inflation & $-5,64$ & $-5,17$ & 0,01 & & & & $\mathrm{I}(0)$ \\
\hline Foreign reserves & $-3,46$ & $-5,17$ & 0,83 & $-8,22$ & $-5,17$ & 0,00 & $\mathrm{I}(1)$ \\
\hline Interest rate & $-3,99$ & $-5,17$ & 0,53 & $-13,26$ & $-5,17$ & 0,00 & $\mathrm{I}(1)$ \\
\hline
\end{tabular}

(Source: Researcher's Computations, 2019)

Table 4 ARDL Bounds Test

\begin{tabular}{lcc}
\hline Banking ASI & Bound 1(0) & Bound 1(1) \\
\hline & 3,12 & 4,25 \\
F-statistic & 4,69 & 4,69 \\
K & 4 & \\
\hline
\end{tabular}

(Source: Researcher's Computations, 2019)

Table 5 ARDL Short-Run Error Correction and Long-Run Estimation - Banking Sector

\begin{tabular}{|c|c|c|c|c|}
\hline \multicolumn{5}{|c|}{ Short-Run Error Correction } \\
\hline Variable & Coefficient & Std. Error & T-Statistic & Prob. \\
\hline D(LOGBANKING(-1)) & $-0,119$ & 0,101 & $-1,178$ & 0,242 \\
\hline $\mathrm{D}(\mathrm{FEX})$ & $-0,245$ & 22,013 & $-0,011$ & 0,991 \\
\hline D(LOGEXRES) & $-6,083$ & 0,073 & $-83,853$ & 0,000 \\
\hline D(INTRATE) & $-0,144$ & 0,007 & $-21,713$ & 0,000 \\
\hline D(INFLATION) & 0,325 & 0,003 & 101,151 & 0,000 \\
\hline D(@TREND ()$)$ & $-0,000$ & 0,002 & $-0,186$ & 0,852 \\
\hline CointEq(-1) & $-0,676$ & 0,067 & $-10,125$ & 0,000 \\
\hline \multicolumn{5}{|l|}{ Long-Run Coefficients } \\
\hline Variable & Coefficient & Std. Error & T-Statistic & Prob. \\
\hline FEX & $-0,363$ & 32,589 & $-0,011$ & 0,991 \\
\hline LOGEXRES & $-9,004$ & 0,965 & $-9,327$ & 0,000 \\
\hline INTRATE & $-0,213$ & 0,018 & $-11,502$ & 0,000 \\
\hline INFLATION & 0,482 & 0,049 & 9,793 & 0,000 \\
\hline $\mathrm{C}$ & $-0,010$ & 4,937 & $-0,002$ & 0,998 \\
\hline @TREND & $-0,001$ & 0,003 & $-0,185$ & 0,853 \\
\hline R-squared & 0,848 & & & \\
\hline Adjusted R-squared & 0,837 & & & \\
\hline F-statistic & 74,001 & & & \\
\hline Prob. (F-statistic) & 0,000 & & & \\
\hline Durbin-Watson stat. & 1,952 & & & \\
\hline
\end{tabular}

(Source: Researcher's Computations, 2019) 
persistent withdrawal of foreign investors from the market for the safety of investment to other countries. Thus, the banking sector is mostly affected by the volume of withdrawal. The banking sector has the largest and most traded equity on the Nigerian stock market with over $60 \%$ total market capitalization (Ajayi, 2013; Zhou \& Huang, 2019; Celebi \& Hönig, 2019) as Nigeria foreign reserves are mainly sourced from crude oil proceeds. According to Central Bank of Nigeria (2018), it is expected to prevent capital flight in the country which are often jeopardized due to lack of proper management and challenges such as youth restiveness, oil bunkering, and kidnapping faced in the oil-producing region of the country.

The research also presents that interest rate has significant negative effects on the stock price behavior of banking sector. It can be because the Central Bank of Nigeria in a bit controls inflation and preserves the foreign reserve by increasing the MPR about $8 \%$. However, the increasing cost of borrowing results in liquidity challenges and reduces corporate earnings, firm profitability, and curtail investment. This result is supported by Khalid and Khan (2017) and Giri and Joshi (2017). They stated that an economy faced with liquidity problems had a negative effect on investment both from the local and foreign investors and adverse effects on stock price behavior.

Furthermore, the result is against Omankhanlen et al. (2016). However, it is in line with the evidence put forth by Kwofie and Ansah (2018). They agreed that the inflation rate had a significant positive impact on the stock price behavior of banking sector. It was because the stock market investment was a good hedge against inflation in Nigeria. These assertions are in line with the APT, which argues that only systematic risk cannot determine the price or return of an asset. The theory support that risk factor arises from changes in fundamental economic and financial variables which can influence the price of assets.

\section{CONCLUSIONS}

Based on the findings, the research concludes that interest rate and foreign reserves have a significant negative impact on the stock price behavior of banking sector both in the short and long run. Meanwhile, the inflation rate positively influences the stock price behavior of banking sector in the long and short run on the Nigerian stock market. Various research in different economies has examined macroeconomic variables and stock market returns on an aggregate basis. However, the research on macroeconomic variables and stock price behavior of banking sector is scarce in the literature. Hence, this research empirically bridges the gap in the literature by examining the stock price behavior of banking sector in response to the unstable macroeconomic variables in the Nigerian stock market.

The research focuses on Nigerian macroeconomic variables and the banking sector among other developing economies. Thereby, it limits the findings only on the Nigerian economy and stock market. The findings cannot be generalized to cover other developing economies and stock markets in Africa. The limitation of this research lies in the availability of funds to cover a wider scope of macroeconomic indicators such as aggregate industrial production, money supply, and corruption index that are critical factors in affecting stock prices in Nigeria.

Based on the findings, the research suggests policy recommendations. First, the Central Bank of Nigeria should reduce the Monetary Policy Rate (MPR) further from the current rate of $13,5 \%$ to a single digit. It is to reduce the cost of borrowing in the country. Hence, it will increase liquidity and drive the investor's interest. As a result, it leads to a better banking sector stock performance. Second, the banking sector, which is the spine of the Nigerian stock market, responds negatively to foreign reserves in the short and long run. Therefore, the research recommends that the foreign reserve should be enhanced and well preserved to reduce capital flight, which will invariably increase the performance of the banking sector in the Nigerian stock market.

Future research should investigate the comparative analysis of how Nigerian stock price behavior in the banking sector react to unstable macroeconomic factors with other developing economies in Africa. Similarly, the research should include other unstable macroeconomic factors that are not used in this research, such as money supply, GDP, national income, and corruption perception index.

\section{ACKNOWLEDGEMENT}

I acknowledge the effort of Abdul-HakeemOloyin Basirat who is my research assistant and Ph.D. supervisee for the sourcing of material and data used for this research.

\section{REFERENCES}

Ajayi, O. I. (2013). Understanding monetary policy sereies no 31. Retrieved from https://www.cbn.gov.ng/ out $/ 2016 / \mathrm{mpd} /$ understanding monetary policy series no 31.pdf

Asamoah, R. O., Baiden, B. K., \& Nani, G. (2019). Towards the establishment of relationship between macroeconomic indicators and cost of public educational buildings in Ghana. Journal of Engineering, 2019, 1-7.

Celebi, K., \& Hönig, M. (2019). The impact of macroeconomic factors on the German stock market: Evidence for the crisis, pre-and post-crisis periods. International Journal of Financial Studies, $7(2), 1-13$.

Central Bank of Nigeria (2018). Central Bank of Nigeria annual report on financial sector in Nigeria. Retrieved from https://www.cbn.gov.ng/documents/ reports.asp 
Gilbert, T., Scotti, C., Strasser, G., \& Vega, C. (2017). Is the intrinsic value of a macroeconomic news announcement related to its asset price impact? Journal of Monetary Economics, 92(December), 7895.

Giri,A. K., \& Joshi, P. (2017). The impact of macroeconomic indicators on Indian stock prices: An empirical analysis. Studies in Business and Economics, 12(1), 61-78.

Khalid, W., \& Khan, S. (2017). Effects of macroeconomic variables on the stock market volatility: The Pakistan experience. Global Journal of Management and Business Research, 17(4-B), 69-91.

Kurotamunobaraomi, T., \& Ebiware, A. E. (2017). Inflation and stock prices: The Nexus. International Journal of Banking and Finance Research, 3(1), 49-58.

Kwofie, C., \& Ansah, R. K. (2018). A study of the effect of inflation and exchange rate on stock market returns in Ghana. International Journal of Mathematics and Mathematical Sciences, 2018, 1-8.

Mbulawa, S. (2015). Stock market performance, interest rate and exchange rate interactions in Zimbabwe: A cointegration approach. International Journal of Economics, Finance and Management, 4(2), 77-88.

Okech, T. C., \& Mugambi, M. (2016). Effect of macroeconomic variables on stock returns of listed commercial banks in Kenya. International Journal of Economics, Commerce and Management, IV(6), $390-418$

Omankhanlen, A. E., Senibi, E. J., \& Senibi, V. K. (2016). Macroeconomic indicators and stock price movement Nexus: A study of the Nigerian stock market. The Social Sciences, 11(13), 3294-3306.
Ouma, W. N., \& Muriu, P. (2014). The impact of macroeconomic variables on stock market returns in Kenya. International Journal of Business and Commerce, 3(11), 1-31.

Pal, S., \& Garg, A. K. (2019). Macroeconomic surprises and stock market responses-A study on Indian stock market. Cogent Economics \& Finance, 7(1), 1-31.

Pesaran, M.H., Shin, Y., \& Smith, R. J. (2001). Bounds testing approaches to the analysis of level relationships. Journal of Applied Econometrics, 16(3), 289-326.

Ray, S., \& Saha, M. (2016). Dynamic association between macroeconomic variables and stock return volatility: Evidence from India. American Journal of Business, Economics and Management, 4(4), 40-56.

Rjoub, H., Civcir, I., \& Resatoglu, N. G. (2017). Micro and macroeconomic determinants of stock prices: The case of Turkish banking sector. Romanian Journal of Economic Forecasting, 20(1), 150-166.

Shrestha, M. B., \& Bhatta, G. R. (2018). Selecting appropriate methodological framework for time series data analysis. The Journal of Finance and Data Science, 4(2), 71-89.

Uwubanmwen, A., \& Eghosa, I. L. (2015). Inflation rate and stock returns: Evidence from the Nigerian stock market. International Journal of Business and Social Science, 6(11), 155-167.

Wooldridge, J. M. (2013). Introductory econometrics: A modern Approach ( $5^{\text {th }}$ ed.). Cengage Learning

Zhou, L., \& Huang, J. (2019). Investor trading behaviour and stock price crash risk. International Journal of Finance \& Economics, 24(1), 227-240. 